\title{
Climate variability in the Spanish Pyrenees during the last 30,000 yr revealed by the El Portalet sequence
}

González-Sampériz, P. ${ }^{1}(*)$; Valero-Garcés, B. L. ; Moreno, A. ${ }^{1}$; Jalut, G. ${ }^{2}$; García-Ruiz, J. M. ${ }^{1}$; Martí-Bono, C. ${ }^{1}$; Delgado-Huertas, A. ${ }^{3}$; Navas, A. ${ }^{4}$ Otto, T. ${ }^{2}$ and Dedoubat J. J. ${ }^{2}$

${ }^{1}$ Instituto Pirenaico de Ecología, CSIC, Avda. Montañana 1005, Apdo 202, 50080 Zaragoza, Spain

${ }^{2}$ LADYBIO Univ. Paul Sabatier - UMR 5172, 29 rue Jeanne Marvig, 31055 Toulouse, France

${ }^{3}$ Estación Experimental de El Zaidín, CSIC, C/ Albareda 1, 18008 Granada, Spain

4 Estación Experimental Aula Dei, CSIC, Avda. Montañana 1005, Apdo 202, 50080 Zaragoza, Spain

(*) Corresponding author:

Penélope González-Sampériz

Pyrenean Institute of Ecology (CSIC)

Apdo 202, Zaragoza, E-50080, Spain

Phone: + 34 976716118; Fax: + 34976716019 


\begin{abstract}
Palynological, sedimentological and stable isotopic analyses of carbonates and organic matter performed on the El Portalet sequence (1802 m a.s.l., 4248’00” N, 0²3’52” W) reflect the paleoclimatic evolution and vegetation history in the Central-Western Spanish Pyrenees over the last 30,000 years, and provide a high-resolution record for the Lateglacial period. Our results confirm previous observations that deglaciation occurred earlier in the Pyrenees than in northern European and Alpine sites, and point to a glacial re-advance from 22,500 to 18,000 cal yr B.P., coinciding with the global Last Glacial Maximum. The patterns shown by the new, high-resolution pollen data from this continental sequence, chronologically constrained by 13 AMS ${ }^{14} \mathrm{C}$ dates, seem to correlate with the rapid climate changes recorded in Greenland ice cores during the last glacial-interglacial transition. Abrupt events observed in northern latitudes (Heinrich Events 3 to 1, Oldest and Older Dryas Stades, Intra-Allerød Cold Period and 8200 yr B.P. event) were also identified for the first time in a lacustrine sequence from the central-western Pyrenees as cold and arid periods. The coherent response of the vegetation and the lake system to abrupt climate changes implies an efficient translation of climate variability from the North Atlantic to mid latitudes.
\end{abstract}

Keywords: Last deglaciation, glacial re-advance, palynology, sedimentology, abrupt climate changes, central-western Spanish Pyrenees. 


\section{Introduction}

Temperature changes of the ocean surface and the position of the North Atlantic Polar Front are known to affect the climate of the neighboring continents, particularly the regions in the downwind direction. The movements of the front are probably coupled with significant alteration of cyclonic trajectories and the connected atmospheric heat and moisture transport patterns (Ruddiman and McIntyre, 1981). Although the characteristics of the main climatic changes of the last 30,000 yr are nowadays well established thanks to the earlier studies of high-resolution marine, ice and continental sequences, the forcing mechanisms and the climate transport processes are a matter of debate. The Iberian Peninsula is an ideal region of study, as it is located in a sensitive climatic zone, thanks to its proximity to the southern position of the North Atlantic Polar Front during the Last Glacial Maximum (LGM) (Ruddiman and McIntyre, 1981). Further, this location makes its climate highly influenced by both high- and low-latitude processes (Prentice et al, 1992; Allen et al., 1996).

Several records from the Iberian Peninsula have shown strong responses of the vegetation to climate fluctuations, such as the warmer and more humid Bølling and Allerød periods, interrupted by the colder and more arid Oldest, Older and Younger Dryas Stades (e.g. Pons and Reille, 1988; Pérez-Obiol and Julià, 1994; Carrión and van Geel, 1999). However, most marine records close to the Iberian Peninsula lack an adequate sedimentation rate or enough sampling resolution to trace these abrupt changes during the last deglaciation (Pujol and Vergnaud-Grazzini, 1989; Cacho et al., 2001; Combourieu Nebout et al., 2002; Roucoux et al., 2005). The available long continental sequences in Spain require better-constrained age models and higher resolution to identify such abrupt changes and show their precise relationship with changes in the North Atlantic (e.g. Padul: Pons and Reille, 1988; Bañolas: Pérez-Obiol and Julià, 1994). 
In this paper we provide a multi-proxy reconstruction of the paleoclimate evolution in the central-western Spanish Pyrenees during the last 30,000 years, based on the El Portalet sequence and supported by a robust chronological framework. The high resolution achieved during the Lateglacial period offers a rare opportunity to investigate the vegetational and limnological response to abrupt climate changes that took place during the Lateglacial in the northern Iberian Peninsula. In addition, since the El Portalet peatbog is located at almost 2000 $\mathrm{m}$ a.s.l., in a glacier cirque, it offers exceptional information about glacier advance and retreat history during the last glacial cycle in the Pyrenees. Our sequence provides new evidence for an early deglaciation in southern Europe compared to northern latitudes, as previously documented at several sites from the Pyrenees (Jalut et al., 1989, 1992; Montserrat, 1992; García-Ruiz et al., 2003; Sancho et al., 2003; González-Sampériz et al., 2005).

\section{Study area}

The El Portalet peatbog (1802 m a.s.l., 42 $48^{\prime} 00^{\prime \prime} \mathrm{N}, 0^{\circ} 23^{\prime} 52^{\prime \prime} \mathrm{W}$ ) is located in the upper part of the Gállego River Basin in the central-western Spanish Pyrenees within a small glacial cirque, closed by a frontal moraine of unknown age (Fig. 1). The bedrock is composed of Devonian and Carboniferous shales and limestones. The cirque is irregularly shaped and its morphology is controlled by the occurrence of limestone outcrops and faults. The Upper Pleistocene glacier of the Gállego valley was the longest in the Spanish Central-Western Pyrenees, descending to $800 \mathrm{~m}$ a.s.l. A number of lateral and terminal moraines have been identified in both the main and tributary valleys reflecting a complex glacial retreat history (García-Ruiz et al., 2003).

The glacier located at El Portalet area was a small tributary of the main Gállego glacier. It was fed by two cirques (Fig.1), the Estremère cirque to the west, and the Peyrelu cirque to the east; both with small ice accumulation potential due to their small size and 
relatively low altitude crests (2100 and $2300 \mathrm{~m}$ a.s.l., respectively). Much of the ice flowed towards a diffluence pass feeding the Ossau Valley glacier to the north; the much smaller southward flowing glacier was responsible for the over-deepening of the El Portalet basin. The timing of the separation of the small Portalet glacier from the main Gállego glacier is difficult to determine because most of the moraines have been reworked by large landslides that are very abundant in the area (Fig.1).

The climate is of a montane type, with Atlantic influence. The average annual precipitation is around $2000 \mathrm{~mm}$ and is mainly associated with fronts coming in from the Atlantic Ocean. During the cold season, the $0^{\circ} \mathrm{C}$ isotherm is located between 1600 and 1700 m. Precipitation clearly increases with altitude, resulting in weaker Mediterranean influences above $1200 \mathrm{~m}$ a.s.l.

Between 1500 and 1750-1800 m, Pinus sylvestris and Quercus faginea forests are abundant and above $1800 \mathrm{~m}$ vegetation is composed of subalpine and alpine pastures (Carex curvula and Festuca scoparia) with small forested areas of Fagus sylvatica, Fraxinus excelsior, Corylus avellana, Betula pubescens, Acer campestre, Sorbus aucuparia and Sorbus aria. Mixed forest with Pinus sylvestris, Fagus sylvatica and Abies alba are also frequent. At present, the vegetation in the peatbog area consists of alpine grasslands due to deforestation during the Middle Ages (Montserrat, 1992).

\section{Methods}

A 6.64 m sediment core was collected using a modified Livingstone corer in the center of the El Portalet peatbog. Sedimentary facies were identified based on colour, lithology, mineralogy, sediment composition and sedimentological structures. Samples for stable isotopes, grain-size, carbonate and organic matter content, and mineralogical analyses were taken every $5 \mathrm{~cm}$. Pollen samples were obtained every 5-10 $\mathrm{cm}$ through most of the sequence, 
increasing the frequency to every $1 \mathrm{~cm}$ along some intervals of the Lateglacial for highresolution analyses.

Organic matter content was determined by loss-on-ignition analyses at $450^{\circ} \mathrm{C}$, and carbonate content was measured with a calcimeter. After oxidation of the organic matter with $10 \% \mathrm{H}_{2} \mathrm{O}_{2}$, grain-size distribution was measured using a Coulter LS 250 laser particle-size analyser. Sediment mineralogy was determined with a Siemens D-500 diffractometer. Oxygen and carbon isotopic compositions were analysed in bulk-sediment samples, and the isotopic values are reported in the conventional delta notation relative to the PDB standard. The $\delta^{13} \mathrm{C}$ values of organic matter were measured after carbonate removal with $\mathrm{HCl}$ 1:1. Analytical precision was better than $0.1 \%$ for $\delta^{18} \mathrm{O}$ and $\delta^{13} \mathrm{C}$ values in carbonates and organic matter.

Extraction of palynomorphs followed the standard procedure described by Moore et al. (1991) modified, using the classical chemical treatment of $\mathrm{HF}, \mathrm{HCl}$ and $\mathrm{KOH}$ with mineral separation in heavy liquid (Thoulet: density 2.0). Exotic Lycopodium clavatum tablets of a known concentration were added to estimate the pollen concentration (Stockmarr, 1971). Results are expressed in relative percentages, excluding spores and hydro- and hygrophytes from the pollen sum. The diagram was constructed using the Psimpoll 4.10 program (Bennet, 2002).

The chronology is based on 13 radiocarbon AMS dates (Table 1). Most samples were pollen concentrates, an efficient technique when terrestrial macro-rests (charcoal, plant remains) are scarce (Brown et al., 1989) and useful to minimize the hard water effect when most pollen taxa are terrestrial (Valero-Garcés et al., 2000). The samples were prepared following the same chemical method used to prepare palynological samples. The accuracy of this method is confirmed by the almost identical ages of two different samples (pollen concentrate and a wood fragment) from the same depth interval (at $371.8 \mathrm{~cm}$ depth, $8610 \pm 90$ and $8420 \pm 80$, respectively) (Table 1 ). 


\section{Results}

\section{Chronostratigraphy}

To construct the age model of the El Portalet sequence, the 13 radiocarbon dates listed in Table 1 were used. These ${ }^{14} \mathrm{C}$ ages have been converted into calendar ages by the CALIB 5.1 software that uses the most updated data set (the INTCAL04 curve; Reimer et al., 2004). The mid-point of $95.4 \%$ ( $2 \sigma$ probability interval) was selected for these dates resulting in errors of \pm 200 years (in average) in the obtained calendar ages. Additionally, another control point (11,500 cal yr B.P.) has been included in the age model, based on the well-known increase of Corylus at the onset of the Holocene on both French and Spanish slopes of the Pyrenees (Jalut et al., 1992; Montserrat, 1992). CALPAL software was used for the two oldest dates, since they were outside the limits of previous calibration. The conversion of ${ }^{14} \mathrm{C}$ ages after 22,000 years is difficult because of the poor knowledge on the quantitative production of cosmogenic ${ }^{14} \mathrm{C}$ along isotopic stage 3 , showing various rises and plateaux and the extremely low residual concentration of ${ }^{14} \mathrm{C}$ in such samples (Bard et al., 2004). The CALPAL software combines the different available approaches to calibrate ${ }^{14} \mathrm{C}$ ages, such as speleothems, corals or varved sediments data (http://www.calpal.de) but the final errors are still too large (aprox. \pm 450 years). Therefore, the calibration difficulties for the oldest dates in this sequence remained an obstacle to a good chronological framework for the base of the sequence.

Finally, an age-depth model was constructed based on interpolated ages between adjacent pairs of dates (Fig. 2). The linear sedimentation rate is highly variable, ranging from 2 to $130 \mathrm{~cm} / 1000 \mathrm{yr}$ (average of $42 \mathrm{~cm} / 1000 \mathrm{yr}$ ). Sedimentation rate is low during glacial times (between 35,000 and 23,000 yr, $7.8 \mathrm{~cm} / 1000 \mathrm{yr}$ in average), increases during the Lateglacial (18,000-13,000 yr, $18.2 \mathrm{~cm} / 1000 \mathrm{yr})$, and reaches the highest values during the Holocene $(63.9 \mathrm{~cm} / 1000 \mathrm{yr})$. There are two intervals with very low sedimentation rates, 
bounded by sharp sedimentological and palynological changes that correspond chronologically to the Last Glacial Maximum (LGM) and the Younger Dryas Stade (YD) (Fig. 2). The El Portalet record spans from 32,440 to 5400 cal yr B.P. The first appearance of Abies and the absence of the Fagus expansion, both characteristic of the Late Holocene in the Pyrenees, confirm that the sequence does not include the last 5000 years.

Since the constructed age model of this sequence represents an independent chronology (i.e. not tuned to Greenland cores), the El Portalet sedimentological and palynological variations can be used to investigate the possible synchronicity and time lag responses through comparison with other records. However, due to the sharp variations of sedimentation rate and the large errors in the oldest dates calibration, this approach was not applied for the whole sequence but only for the last deglaciation interval. Accordingly, the timing for the main abrupt changes is taken from GRIP ice core, as proposed by the INTIMATE group (Bjorck et al., 1998). The response of the main sedimentological and palynological proxies during these events is then evaluated.

\section{Sedimentology}

Based on the sedimentology, grain-size distribution, mineralogy, organic matter and carbonate contents, eleven sedimentary units were defined (Fig. 3). The base of the sequence (Unit 11, 655-608 cm depth, older than 32,900 cal yr B.P.) represents the unsorted and massive glacial till, composed of cm-sized clasts within a silty-clayey matrix of clay minerals (illite, kaolinite, and chlorite) and quartz. The El Portalet lacustrine sediment sequence is dominated by massive, siliciclastic, low-carbonate, bluish-gray silts at the base (Units 10 and 9) with increasing greenish-gray, carbonate-rich silts (Units 8 and 7), that eventually became dominant (Unit 6). Unit 5 is characterized by high organic-matter content and laminated facies. Unit 4 is composed of gray, carbonate-rich silts. The upper units (3 to 1 ) are dominated by peat layers. 
Unit 10 (608-570 cm depth, 32,900-28,100 cal yr B.P.) is interpreted as deposition in a pro-glacial lake developed after glacier retreat, but still greatly influenced by glacier melting processes and pro-glacial stream activity. The occurrence of several mm-thick, quartz-rich fine-sand layers and dropstones intercalated in the massive, siliciclastic, bluish-gray silts highlights a strong glacial influence. The presence of cm-thick, laminated, greenish-gray silts intercalated with bluish-gray silts characterizes Unit 9 (570-537 cm depth, 26,900 -23,500 cal yr B.P.). The absence of dropstones and sandy layers, and the laminated nature of the sediments suggest the dominance of lacustrine dynamics with less proglacial influence. An interval of massive, bluish gray silts, suggesting the return of proglacial influence, occurs at the top of the unit (545-537 cm depth, 24,600-23,500 cal yr B.P.) which, according to GRIP ice core chronology, corresponds to the Heinrich event 2. Both an erosive surface and a sharp change in sedimentary facies suggest a sedimentary hiatus at the top of Unit 9. As we discuss later, a glacier re-advance is the most likely cause for this depositional unconformity, which coincides with the LGM period. Unit 8 (537-485 cm depth, 23,100- 15,500 cal yr B.P.) is composed of an alternation of carbonate-rich greenish-gray silts and thinner, finer, carbonatepoor gray silt layers. Although the carbonate fraction has a double source (detrital from the surrounding Paleozoic rocks and authigenic precipitated in the lake), the occurrence of bioclasts points to increasing biological productivity in the lake, consistent with the beginning of the deglaciation interval. The deposition of gray silts (mid part of subunit 8A: 502-498 cm) suggests a return towards colder conditions for a short period $(16,500-16,300 \mathrm{cal}$ yr) that may correspond to the cooling generally associated with Heinrich event 1 , within the uncertainties of our age model.

Similar alternation of dark gray silts and carbonate-bearing greenish silts occurs in Unit 7 (485-408 cm 15,500-12,900 cal yr B.P.), although the carbonate content is still low. Deposition of dark gray siliciclastic silts with low carbonate and organic matter content in 
Subunit 7D (485-470, 15,500-14,700 cal yr B.P) and 7B (458-440 cm, 14,000-13,400 cal yr B.P.) indicates less organic productivity in the lake consistent with the colder climate during the Oldest and Older Dryas Stades. Along Subunit 7C (470-458 cm, 14,700-14,000 cal yr B.P.), greenish-gray, carbonate-rich silt layers become more abundant, pointing to warmer conditions during the Bølling period. Within subunit 7A (440-408 cm, 13,400-12,900 cal yr B.P.) composed of massive, dark silts, with low macro-rest content, there is a slight decrease in carbonate content for a short interval $(408-419 \mathrm{~cm})$ that may correspond to another cold event within the Allerød period. The carbonate content increases again towards the top (Fig. 3).

Unit 6 (408-322 cm depth, 12,900-8500 cal yr B.P.) has the highest carbonate content in the sequence (up to 70\%) and is also characterized by an increase in organic matter (10-30\%). Changes in carbonate and organic matter content define three subunits: carbonate-rich (Subunit 6C, 408-385 cm depth, 12,900-12,600 cal yr B.P.), carbonate-poor (Subunit 6B, 385-372 cm depth, 12,600-9600 cal yr B.P.), and carbonate and organic-matter rich (Subunit 6A, 372-320 cm depth, 9600-8500 cal yr B.P.). Unit 6 facies indicate a highly productive carbonate lake corresponding to the last part of the Allerød period and the transition to the Early Holocene. The very low sedimentation rate during Subunit 6B (3000 years in $14 \mathrm{~cm}$ ) suggests the presence of a small hiatus prior to the onset of the Holocene.

High organic matter content (30\%) characterizes Unit 5 (320-227 cm depth, 8500-6900 cal yr B.P.). Carbonate-rich and organic-rich silts with abundant mollusk and macrophyte remains (also indicated by an increase in grain-size, Fig. 3) in Subunit 5C (320-292 cm, 8500 - 8000 cal yr B.P.) are interpreted to reflect deposition in a shallow, carbonate-lake. The massive, black, organic-rich, carbonate-poor silts of Subunit 5B $(292-280$ cm, 8000-7800 cal yr B.P.) represent deposition in a relatively deeper lake with reduced clastic input and dominated by organic sedimentation. Decreasing organic content and increasing carbonate in 
Subunit 5A, (280-227 cm, 7800-6900 cal yr B.P.) reflect a shallowing trend in lake level, that continues with the deposition of carbonate-rich and organic-poor, massive, dark gray silts in littoral environments in Unit 4 (227-200 cm depth, 6900-6400 cal yr B.P.). The decrease in lake level led to the establishment of a peatbog after 6400 yr. Unit 3 (200-130 cm depth, 6400-5800 cal yr B.P.) consists of degraded massive peat, with some levels composed of reworked macro-rests eroded and re-deposited. After 5800 yr (Unit 2, 130-70 cm, 5800-5300 cal yr B.P.), periods of peat deposition (cm-thick levels of dark brown peat with macro-rests) alternate with shallow clastic lake deposition dominated by gray quartz-rich silts lacking carbonate. The upper $70 \mathrm{~cm}$ of the El Portalet sequence (Unit 1), not sampled for analyses, represent the peat-bog developed during the last millennia till present-day.

\section{Stable isotopic composition of carbonates and organic matter}

The interpretation of isotope data from bulk carbonate samples is complex because of the different sources of carbonate in lake sediments (e.g. Talbot, 1990). Smear slide observations indicate that in the El Portalet sediment sequence, most of the carbonate fraction is made of macrophyte coatings, Chara remains, shells, and bioclasts. However, in some intervals, mainly when El Portalet basin was occupied by a pro-glacier and a siliciclastic lake, carbonate fragments from the marine Paleozoic bedrock are also a significant, and sometimes dominant, source. The isotopic signature of the Carboniferous limestone is characterized by low oxygen and high carbon values $\left(\delta^{18} \mathrm{O}=-13.52 \%\right.$ PDB and $\delta^{13} \mathrm{C}=+1.79 \%$ o PDB). In spite of these difficulties, the isotope record of carbonates from the El Portalet sequence provides some additional information on the limnological and hydrological evolution of the lake system.

The observed range of $\delta^{18} \mathrm{O}$ values (-6 to $-14 \%$ PDB) is typical of freshwater systems, largely influenced by meteoric waters, in a hydrologically open system with short residence 
times (Fig. 3). In most cases, two main processes influence the $\delta^{18} \mathrm{O}$ values in such lake systems: (1) the effective moisture (precipitation - evaporation) and (2) the isotopic composition of rainwater (e.g. Griffiths et al., 2002). The highest $\delta^{18} \mathrm{O}$ values come from Units 10 and 9, a period that corresponds to Oxygen Isotopic Stage, OIS 3 when an enrichment in ${ }^{18} \mathrm{O}$ values in the meteoric waters, due to enhanced global ice volume during glacial times occurred. Similar patterns have been documented in the isotope record from Bañolas Lake, eastern Pyrenees, where the most positive values where attained during the last glacial period (Valero-Garcés et al., 1998). On the contrary, in the absence of large changes in rainfall $\delta^{18} \mathrm{O}$ values, decreasing $\delta^{18} \mathrm{O}$ trends in the El Portalet carbonate sediments can be interpreted as a reflection of greater moisture availability. This situation is observed both during the Lateglacial (Units 8 and 6C) and the Early to Middle Holocene (Units 5 and 4). In Unit 5, where clastic carbonate input is minor, peaks in carbonate content correlate with higher $\delta^{18} \mathrm{O}$ values, suggesting higher evaporation in more carbonate-producing littoral lacustrine environments during periods of lower lake levels.

In the absence of precipitation of carbonates during diagenesis, changes in the $\delta^{13} \mathrm{C}_{\text {calcite }}$ reflect variations of the DIC (Dissolved Inorganic Carbon) input values and changes in the limnological and biological parameters of the lake, such as $p \mathrm{H}$, alkalinity, productivity, oxidation of organic matter in the sediments, equilibrium with atmospheric $\mathrm{CO}_{2}$ evaporative and residence time effects (Talbot, 1990; Leng and Marshall, 2004). However, the markedly positive $\delta^{13} \mathrm{C}$ values observed at the basal units from El Portalet record suggest the presence of detrital carbonate from the surrounding Paleozoic rocks $\left(\delta^{13} \mathrm{C}\right.$ $=+1.79 \%$ PDB), thus preventing an explanation in terms of vegetational or limnological changes along Units 10, 9 and 8. In a pro-glacier environment the input of sediments from the surrounding areas would have been favored. For the rest of the sequence, a clear correspondence among the increase in the percentage of carbonate and less negative values 
of $\delta^{13} \mathrm{C}$ supports its interpretation as variations in lake productivity during the Lateglacial and Early to Mid-Holocene (McKenzie, 1985). Accordingly, the increase in authigenic carbonate production observed during Units 6, 5 and 4 may represent an enhancement of lacustrine productivity. This lake productivity increment would have lead to higher DIC $\delta^{13} \mathrm{C}$ values through biological activities and then more positive $\delta^{13} \mathrm{C}$ values in the precipitating carbonates.

Sources of organic matter in lacustrine sediments are terrestrial plants and aquatic higher plants and algae, displaying characteristic carbon isotope compositions (Meyers, 2003). The isotopic signatures of plants utilizing atmospheric $\mathrm{CO}_{2}$ can be used to distinguish between those that employ the $C_{3}$ synthetic pathway $\left(\delta^{13} C_{\text {org }}=-33 \%\right.$ to $-22 \%$ ) and $C_{4}$ plants $\left(\delta^{13} \mathrm{C}_{\text {org }}=-16 \%\right.$ o to $-9 \%$ ), which are favored by aridity and low $\mathrm{CO}_{2}$ partial pressures (Meyers and Lallier-Vergès, 1999). Besides this process, the $\delta^{13} \mathrm{C}_{\mathrm{org}}$ for lacustrine algae and submerged aquatic macrophytes varies markedly with the isotope value of the source carbon and with the degree of isotopic fractionation with respect to the source (Griffiths et al., 2002). The $\delta^{13} \mathrm{C}_{\text {org }}$ values from the El Portalet sequence show four different intervals that can be correlated to the main changes in the lake sequence (Fig. 3): a) $\delta^{13} \mathrm{C}$ values of between -25 and $-20 \%$ in Units 10,9 and 8 (from OIS 3 to $\approx 16,000$ cal yr B.P.) point to a minor contribution of lacustrine organic matter in a glacial-related lake and a possible slight influence of $\mathrm{C} 4$ biomass in the catchment favored by the lower $\mathrm{CO}_{2}$ partial pressures during glacial periods. b) The intermediate and generally decreasing values from Unit 7 and the lower part of Unit 6 ( $\approx 16,000-13,000$ cal yr B.P.) suggest increasing biological productivity in the lake coherently with the Lateglacial and Early Holocene periods. c) The next interval ( $\approx 13,000-6500$ cal yr B.P.) shows lower and less variable values (-29 to $-26 \%$ o) during the development of the carbonate and organic phases of the lake. d) Values from the peat units 
are relatively constant, increasing only slightly. The low values at the top correspond to the last shallow lake interval.

\section{Pollen stratigraphy}

The description and interpretation of the palynological data of the El Portalet sequence (Figs. 4 to 6) is organized into five pollen zones (P1-P5) following the main vegetation trends. Since Pinus, Juniperus, Betula, Corylus, Artemisia and other steppe taxa are the main components of the pollen spectra, we used them to determine the different stages of the vegetational history.

In pollen zone P1 (608-540 cm, 32,900-23,900 cal yr B.P.), the glacial herbaceous component is as high as $60 \%$, with the highest fraction of Artemisia (30\%), and relatively high values of other steppe taxa (10-20\%) and Poaceae. The arboreal group is limited to Pinus and Juniperus, with the presence of few mesothermophytes (1-2\%) that would probably represent long-distance transport (Fig.4). According to their current distribution in the Central Spanish Pyrenees (http://www.ipe.csic.es/floragon), the most likely pine and juniper species at this altitude during glacial periods would be Pinus uncinata and Juniperus communis alpina. This pollen zone, corresponding in time to the latter part of OIS3, is characterized by significant pollen variability, mainly in steppe taxa (including Artemisia), Juniperus and Pinus. The pine (20-50\%) and juniper (5-10\%) pollen found may have arrived via long distance transport which, at that time, was favoured by the limited vegetation cover on the site (steppe herbaceous formations). Stronger atmospheric circulation inferred during the OIS 3 (e.g. Moreno et al., 2002), also facilitated the aforementioned long distance transport.

According to the GRIP ice core age and taking into account the uncertainties of our age model, Heinrich event 3 corresponds in our sequence to the 590-580 cm depth interval (30,700-29,500 cal yr B.P.) and Heinrich Event 2 to the 550-537 cm depth interval (25,10023,500 cal yr B.P.). During these intervals a decrease in Juniperus and increases in steppe 
taxa are observed in Figure 5 where selected pollen curves are plotted versus age (variations in sedimentation rates difficult the observation of abrupt changes in depth profiles, Fig. 4). Although Pinus decreases could be related in most western Iberian marine sequences to cold and arid climatic changes, particularly the HE (i.e. Sánchez-Goñi et al., 2002; Roucoux et al., 2005), we don't find the same pattern at El Portalet sequence. Since the most likely pine species in the Central Spanish Pyrenees during the last glacial period, Pinus uncinata, lives through very cold winters, strong winds and supports several dry summers (Camarero et al., 1998) it would not be as sensitive to temperature and aridity changes of the Lateglacial as Juniperus communis. Botanical and ecological studies (García et al., 2002) demonstrate that juniper is controlled by climatic factors, such as cold winters coupled with dry summers that ultimately limit pollen availability and depress vegetative growth and reproductive output. Therefore, we suggest that Juniperus may be better indicator of rapid climatic changes than Pinus in El Portalet (Figs. 5).

A patchy glaciated landscape dominated by Artemisia and other steppe taxa is consistent with the very cold and arid conditions postulated during Heinrich events described in marine sequences (Sánchez-Goñi et al., 2002; Turon et al., 2003; Roucoux et al., 2005). In fact, a decrease of 5 to $10^{\circ} \mathrm{C}$ in the sea-surface temperatures (SST) from the Portuguese margin and the Alboran Sea was deduced for some of the Heinrich events (Cacho et al., 2001).

Pollen Zone P2 (540-520 cm, 23,900-17,800 cal yr B.P.) has been defined based on the occurrence of sharp peaks in some pollen taxa (mainly Pinus and Poaceae) (Fig. 4). These sharp peaks suggest the presence of hiati in the sedimentary sequence, supporting other sedimentological and chronological evidence. This period is constrained between 22,500 to 18,000 cal yr B.P., and probably corresponds to a glacier re-advance during the cold intensification of the Last Glacial Maximum. The Artemisia peak at $520 \mathrm{~cm}$ depth (Fig. 4) 
should correspond to the well-known peak of Artemisia recorded on both Spanish and French slopes of the Pyrenees around 15,000 ${ }^{14} \mathrm{C}$ yr B.P. (18,000 cal yr B.P.) (Jalut et al., 1992; Montserrat, 1992; Reille and Lowe, 1993).

Increases of AP values, total PC concentration and AP taxonomic diversity in Pollen Zone P3 (520-382 cm, 17,800-12,500 cal yr B.P.), mainly in its upper part, suggest an enhancement of local pollen productivity in this zone that would correspond to the Lateglacial climatic warming. In this period, some mesophytes (mainly Betula) as well as pines and junipers develop, acting as tree pioneers during the Bølling and Allerød warm periods. A temperature increase is also marked in lake water productivity by Ranunculaceae percentages, similarly to that observed in other Pyrenean sequences (Jalut et al., 1992; Reille and Lowe, 1993). The high-resolution pollen analyses carried out in this zone reveal the complex Lateglacial climate variability (15,000-12,500 cal yr B.P.), marked by abrupt changes in the abundance of some taxa, such as Pinus, Juniperus, Poaceae, Artemisia, other steppe taxa and hydro- and hygrophytes.

According to the GRIP ice core chronology, some of these abrupt changes (mainly seen in some decreases in the Juniperus curve and the increases in steppe taxa) could be related to the HE1, Oldest and Older Dryas States and the Intra-Allerød-Cold-Period events (Fig. 6). There is no clear evidence from the palynological data for arid and cold conditions at the time of the YD chronozone. This period is evident in all available Pyrenean sites, commonly expressed as a general decrease in the arboreal pollen component and an increase in the steppe taxa (Jalut et al., 1992; Montserrat, 1992; Reille and Lowe, 1993). We would expect in El Portalet, during the YD Stade, an abrupt decrease of Betula and other mesophytes that expanded during the Allerød period. Instead, we find a continuous evolution from the Allerød vegetational composition to the rapid development of Corylus of the Early Holocene in the Pyrenees (e.g. Jalut et al., 1992; Montserrat, 1992). In order to confirm the absence of a 
YD pollen signal, we sampled every centimeter in the interval $385-382 \mathrm{~cm}$ depth, and some centimeters more above and below (395-380 cm depth). The palynological signal detected in these samples remained coherent with the Allerød spectra, dominated by Pinus, Betula and Juniperus in the arboreal component. The absence of a clear vegetational response to the YD Stade leads us to propose that lacustrine sedimentation was interrupted at this time. The relatively high altitude of El Portalet site (1802 m a.s.l., the highest altitude Lateglacial record studied in the Spanish Pyrenees) resulting in colder temperatures and stronger winds than in lower sites could be responsible for the freezing of lake surface and consequent lack of sedimentation.

A rapid substitution of Betula with Corylus, and a minor expansion of deciduous Quercus and other mesophytes occur in Pollen Zone P4 (381-230 cm, 11,500-6900 cal yr B.P.), corresponding to the Early Holocene. The typical Betula-Quercus-Corylus succession appears in all Pyrenean records, on both northern and southern slopes (Jalut et al., 1992; Montserrat, 1992; Reille and Lowe, 1993). The large presence and the rapid increase of Corylus in this location and the absence of the usually first Quercus development could be related at El Portalet site to three factors. First, the relatively high altitude of the site. At present, Quercus species existing in the southern slopes of the Pyrenees do not live higher than 1500-1700 m a.s.l., while Corylus formations reach $1900 \mathrm{~m}$ a.s.l. (see http://www.ipe.csic.es/floragon/). Second, the proximity of Corylus refuge areas during the Lateglacial in the Ebro River Valley and the Pyrenean tributaries (e.g. Salada Mediana: Valero-Garcés et al., 2000) and finally, the stronger oceanic influence that results in the dominance of Corylus in the AP composition instead of the usual deciduous Quercus characteristic of southern European continental records (Montserrat et al., 1992; Pérez-Obiol and Julià, 1994; Allen et al., 1996; Magri, 1999). 
According to our chronological model, the decrease in Juniperus, Betula, Corylus, deciduous Quercus and other mesophytes percentages between 312-290 cm depth may correlate with the climate deterioration postulated for the $8200 \mathrm{yr}$ event (Alley et al., 1997). Although other abrupt pollen changes occurred during the Early Holocene (Figs.4 and 6), this interval shows the clearest signal and, additionally, presents some sedimentological evidences for shallower lake level (Subunit 5C) (Fig. 3).

In Pollen Zone P5 (230-75 cm, 6900-5300 cal yr B.P.), the spectra show the first Abies peak and a varied mixed forest of conifers and mesothermophytes, indicating the establishment of altitudinal vegetation stages in the region. An increase in the abundance of hydro- and hygrophytic pollen taxa, mainly due to the expansion of Cyperaceae, indicates a shallowing trend that ends with the establishment of a peat bog after 6400 cal yr B.P. (sedimentary Unit 3). At the top of this pollen zone, conifers and herbaceous taxa (particularly the steppe component and Poaceae) increase, suggesting an open landscape with a minor presence of mesophytes and a lower diversity of pollen taxa. This is the usual substitution observed in the Middle Holocene in the Pyrenees that concludes with the first Abies development. The large parallel Fagus expansion usually recorded at 4000 yr B.P. (Andrieu et al., 1988; Jalut et al., 1992; Reille and Lowe, 1993; Montserrat, 1992) is not observed at El Portalet, thus supplying an additional chronological control for the top of this sequence.

\section{Discussion}

\section{Early Deglaciation in southern Europe}

Several glacial records from both northern and southern slopes of the Pyrenees have shown ages consistent with an earlier deglaciation compared to Northern European sites (Jalut et al., 1989). However, this hypothesis has been challenged by consideration of hard water effects in the ${ }^{14} \mathrm{C}$ ages (see García-Ruiz et al., 2003 for a review). Similar conclusions on 
early deglaciation have been reached in other European mountains such as the Alps and the Vosgues (Montjuvent and Nicoud, 1988; Seret et al., 1990; Guiter et al., 2005). The base of the El Portalet sequence has been dated to $28,300 \pm 370{ }^{14} \mathrm{C}$ yr $(32,183-33,773$ cal yr B.P.) indicating that the El Portalet cirque located at $1802 \mathrm{~m}$ a.s.l. was already ice-free at this point in OIS 3. This new evidence, together with other dates arrived at through study of several Pyrenean paleoclimate archives, such as lake records (Jalut et al., 1992; Montserrat, 1992; García-Ruiz et al., 2003), stratified screes (García-Ruiz et al., 2001) and fluvial terraces (Sancho et al., 2003), confirm that most Pyrenean glaciers on the southern slopes had retreated from their maximum extent by 30,000 yr. The southern latitude of the Pyrenean Spanish slope that implies a particular climatic situation characterized by less precipitation and perhaps high summer temperatures (Montserrat, 1992) may be the direct cause for the early glacier retreat.

In spite of the reduced size of the El Portalet cirque and the importance of local factors (sunny exposure and relatively low altitude compared with other Gállego River head-water cirques), this record may provide some additional evidence for possible glacier re-advances of the Gállego River glacier. A glacier re-advance can be postulated based on i) the presence of an erosive surface, ii) sharp changes in the vegetation association, and iii) very low sedimentation rates or even lack of sedimentation during some intervals. We identified these three conditions in the El Portalet sequence during the LGM (22,500 to 18,000 cal yr B.P.): lower sedimentation rates, sharp peaks in pollen spectra (particularly in the Pinus and Poaceae curves) that do not correspond with the expected vegetation behaviour, and the presence of an erosive surface in the sediments. A small glacier could have occupied the El Portalet cirque and eroded part of the sedimentary sequence or would have prevented the normal lacustrine sedimentation (Fig. 3). 
A number of glacial re-advance phases have been identified in the Pyrenees during the LGM and Lateglacial cold events, with well-preserved terminal moraine complexes and debris-covered glaciers (García-Ruiz et al., 2003). Nevertheless, local factors such as small size, relatively low altitude and sunny exposure, limited glacial re-advances during the Lateglacial in some cirques. In the El Portalet cirque, only one glacier re-advance (LGM) can be inferred from the sedimentary and palynological record. Lateglacial cold events can be identified using sedimentological and palynological data in the El Portalet because they are not associated with any erosive hiati, whereas in neighboring, north-facing valleys within the Upper Gállego basin, glacial tongues up to $4 \mathrm{~km}$ in length developed during the Lateglacial. As a result, this high altitude record is more continuous than that from other sites in the Pyrenees, allowing a more detailed paleoclimatic reconstruction of the Lateglacial period.

The other striking decrease in the sedimentation rates observed in Figure 2, although occurring over a shorter interval, corresponds to the YD Stade. In this case, no erosive surface or sharp changes in the vegetation cover were detected. Consequently, our data suggest that the cirque was not totally occupied by a glacier at that time, and that there was no erosion of the sediment. Permanent freezing of the lake probably interrupted the normal sedimentation and pollen rain during this event. However, in spite of cold temperatures, a glacial re-advance was not possible because of the short time-span of the YD Stade and its marked aridity (Jalut et al., 1992; Montserrat, 1992). In comparison, the colder temperatures of the LGM maintained during a longer time, may have been enough to produce glacier re-advance in the El Portalet cirque. The El Portalet sequence is located at a higher altitude than other Pyrenean records, thus the freezing of the lake during those periods is more plausible. Since no evidence of lake freezing was detected during other cold events, we suggest that the YD Stade may have been the coldest of the Lateglacial events in the Pyrenees. 


\section{Abrupt climatic fluctuations along last glacial-interglacial transition}

Several abrupt climate fluctuations are detected in the El Portalet sequence during the last 32,000 yr. Our study shows simultaneous vegetation and sedimentological changes (Table 2) that seem to respond to the abrupt climate fluctuations previously recognized in marine and ice sequences (Björck et al., 1998; Johnsen et al., 2001; Sánchez-Goñi et al., 2002; Roucoux et al., 2005). To illustrate this correlation more clearly, both pollen and sedimentological signals at El Portalet sequence are compared in depth and time and, simultaneously, correlated to the GRIP ice core in Table 2.

The two time intervals that correspond, according to GRIP ice core chronological model, to Heinrich Events 3 and 2 show distinctive sedimentological and palynological features in the El Portalet sequence. The interval that corresponds to HE3 (at the base of the sequence) is marked as a sandier layer at 595-585 cm depth corresponding to 31,400-30,100 cal yr B.P. The top of sedimentary unit 9 is characterized by bluish gray massive silts that correspond in time with HE2 (545-537 cm; 24,600-23,500 cal yr B.P.). The increases in pollen percentages for steppe taxa and decreases in Juniperus during both HE3 and HE2 (Fig. 5, Table 2), may point to the establishment of cold and dry conditions during these two events. Additionally, the observed variations in juniper and steppe taxa curves below and above these two HE can correspond to the well-known climate changes in between $\mathrm{HE}$ (dashed lines in Fig.5). However, the low sedimentation rates throughout the glacial period (Fig. 2), calibration difficulties for dates older than 24,000 yr and the fact that El Portalet was a lake very influenced by glacier dynamics, prevents further inferences on the timing and climate characteristics of these events. On the contrary, the sedimentation rate during the last glacial-interglacial transition in the El Portalet sequence is high enough to allow the investigation of abrupt climate fluctuations in detail. 
In Figure 6, several selected proxies from this sequence and the $\delta^{18} \mathrm{O}$ curve from GRIP ice core are plotted versus age to better discern the abrupt climate changes of the last deglaciation. During some intervals of the Lateglacial, steppe taxa increase, Juniperus decreases and deposition in the lake is dominated by gray siliciclastic silts, which provoke sharp decreases in the carbonate content (from 20 to 1\%) (Fig.6, Table 2). This is the case for the events correlated with the Intra Allerød Cold Period (IACP) and the Older Dryas Stade (GI-1b and GI-1d in GRIP terminology, Bjorck et al., 1998), as well as for the Oldest Dyas Stade and the Heinrich Event 1 (HE1). Sedimentological and palynological data indicate that, during these global events, conditions were cold and arid in the area. On the contrary, during the last deglaciation warmer intervals, such as the Bölling (GI-1e) and Allerød (GI-1c and GI1a) periods, increases in Juniperus, temperate taxa (Betula, Corylus, Quercus, other mesophytes) and Ranunculaceae, are observed together with the presence of organic-rich silts with higher percentages of carbonate (Fig. 6, Table 2).

The El Portalet site is likely particularly sensitive to the high variability of the complex Lateglacial period due to its high altitude. Additionally, the observed vegetation changes in this sequence seem to respond to climatic changes and not only to other biotic factors (e.g. population dynamics, edaphic conditions). It is likely that the open Lateglacial vegetation formation was close to the limit of its favorable ecological conditions, and consequently was very vulnerable and responded quickly to rapid climate changes. Particularly, Juniperus communis would be very sensitive to summer droughts at this altitude while Pinus uncinata may support some dryness, similarly to their present-day life conditions in the Central Spanish Pyrenees (Camarero et al., 1998; García et al., 2002).

The El Portalet sequence also provides some evidence of the possible impact of global Holocene cold episodes in the Pyrenees, particularly the cold event defined in Greenland at 8200 cal yr B.P. and in marine cores (e.g. Bond et al., 1997; Alley et al., 1997). According to 
our chronological model, the 8200 yr event (312-290 cm depth) is marked by a decrease in forest formation (Juniperus, Betula, Corylus, deciduous Quercus and other mesophytes), more positive values in $\delta^{13} \mathrm{C}_{\text {org }}$ profile and sedimentary facies that indicate shallower conditions (Table 2). However, this is not the only interval of such characteristics during the Holocene in El Portalet record.

Although some of these abrupt changes can be seen in pollen sequences from the Iberian Peninsula (see e.g. Allen et al., 1996 or Carrión and van Geel, 1999), they are particularly evident in El Portalet, probably due to i) the high-sensitivity of this area to fluctuations in the North Atlantic climate, ii) the altitude of the site and iii) the high-resolution analyses. These events are observed as short and abrupt pulses during the general trend of the last deglaciation towards warmer and wetter conditions. The absence of authigenic carbonates precipitating in the lake during most of the glacial-interglacial transition prevents us from using stable isotopes in carbonates as paleolimnological and paleohydrological proxies.

Comparison with the GRIP ice core (Fig.6, Table 2) shows similar evolution during the last glacial-interglacial transition. Therefore, we conclude that short-term climate variability from high latitudes modulated the climate evolution of the central-western Spanish Pyrenees during the last 30,000 yr. Most likely, the transfer mechanisms from northern Atlantic regions to the Iberian Peninsula were almost instantaneous. Among the main driving mechanisms able to have almost immediate effects are colder and drier northwesterly winds, colder SST entering through the Strait of Gibraltar, or meltwater pulses originating from the Scandinavian ice sheet, as previously suggested for other Mediterranean records (Magri and Parra, 2002; Sangiorgi et al., 2002; Tzedakis et al., 2003; Bahr et al., 2005). 


\section{Conclusions}

Palynological, sedimentological and stable isotopic analyses performed on the El Portalet sequence reflect the paleoclimatic evolution and vegetation history in the CentralWestern Pyrenean Range for the last glacial and Holocene periods. The basal age of the sequence (ca 33,000 cal yr B.P.) confirms that the last deglaciation occurred earlier in the Pyrenees than in northern latitudes of Europe. Both, sedimentological and palynological evidences indicate a glacier readvance during the LGM (22,500 to 18,000 cal yr B.P.). An interruption in sedimentation during the YD Stade, suggests that the lake may have been frozen, although this period was not long enough to result in any substantial glacier readvance.

The high-resolution record at El Portalet reveals abrupt climatic changes that can be correlated with regional cold events. The altitude and the strong influence of the North Atlantic climate seem to be important factors in explaining the presence and intensity of these abrupt periods previously defined in ice and marine paleorecords. Accordingly, the HE and other periods of rapid climate change, such as the Oldest and Older Dryas Stades, IACP and even the 8.2 event, are recorded here by the presence of gray siliciclastic silts with low carbonate content and systematic vegetation changes, suggesting a response to cold and arid conditions. The warmer Bølling and Allerød periods correspond with higher abundances of mesophytic taxa and carbonate-producing lake phases. These Lateglacial and Holocene events are here documented for the first time in northeastern Spain, thanks to high-resolution multiproxy analyses, facilitated by the elevated sedimentation rates. The driving mechanisms for this variability may be related to a rapid atmospheric teleconnection, such as variations in the intensity of the westerly wind system that transferred the climatic conditions that have characterized the last glacial-interglacial cycle in the North Atlantic. 


\section{Acknowledgements}

This study was partially funded by projects REN 2000-1136/CLI, REN2003-02499GLO and REN-2003-09130-CO2-02, by the CICYT and PI-17/00739/FS/01 (Fundación Séneca). Funding for P.G.S. was provided by the Spanish Government (post-doctoral grant in UPS-Toulouse, France). We are very grateful to P. Serrano for her help with the study area cartography and to B. García, J.S. Carrión and M. Dupré for their thoughtful suggestions. We thank to editor J. Quade, M.F. Sánchez-Goñi and another anonymous referee for their helpful comments on an early version of the manuscript.

\section{References}

Allen, J., Huntley, B., Watts, W. 1996. The vegetation and climate of the northwest Iberia over the last 14.000 yr. Journal of Quaternary Science 11, 125-147.

Alley, R. B., Mayewski, P. A., Sowers, T., Stuiver, M., Taylor, K. C., Clark, P. U. 1997. Holocene climatic instability: A prominent, widespread event 8200 yr ago. Geology 25, 483-486.

Andrieu, V.; Hubschman, J; Jalut, G., Herail, G. 1988. Chronologie de la déglaciation des Pyrénées francaises. Dynamique de sédimentation et contenu pollinique des paléolacs: Application á l’interprétation du retrait glaciaire. Bulletin A.F.E.Q. 2/3, 55-67.

Bard, E., Rostek, F., and Ménot-Combes, G. 2004. A better radiocarbon clock. Science 303, 178-179.

Bahr, A., Lamy, F., Arz, H. W., Kuhlmann, H., Wefer, G. 2005. Lateglacial to Holocene climate and sedimentation history in the NW Black Sea. Marine Geology 214, 309-322.

Bennet, K. 2002. Documentation for Psimpoll 4.10 and Pscomb 1.03. C programs for plotting pollen diagrams and analysing pollen data. University of Cambridge. Cambridge.

Björck, S., Walker, M. J. C., Cwynar, L., Johnsen, S. J., Knudsen, K.-L., Lowe, J. J., Wohlfarth, B., Group, I. 1998. An event sratigraphy for the last termination in the North Atlantic based on the Greenland Ice core record: a proposal by the INTIMATE group. Journal of Quaternary Science 13, 283-292. 
Bond, G., Showers, W., Cheseby, M., Lotti, R., Almasi, P., de Menocal, P., Priore, P., Cullen, H., Hajdas, I., Bonani, G. 1997. A pervasive millenial-scale cycle in North Atlantic Holocene and glacial climates. Science 278, 1257-1266.

Brown, T; Nelson, D; Mathewes, R; Vogel, J., Sonthon, J. 1989. Radiocarbon dating of pollen by accelerator mass spectrometry. Quaternary Research 32, 205-212.

Cacho, I., Grimalt, J. O., Canals, M., Sbaffi, L., Shackleton, N. J., Schönfeld, J., Zahn, R. 2001. Variability of the Western Mediterranean sea surface temperatures during the last 25,000 years and its connection with the northern hemisphere climatic changes. Paleoceanography 16, 40-52.

Camarero, J., Guerrero, J., Gutiérrez, E. 1998. Tree-ring growth and structure of Pinus uncinata and Pinus sylvestris in the Central Spanish Pyrenees. Arctic and Alpine Research, vol 30, 1, 1-10 pp.

Carrión, J. S. and van Geel, B. 1999. Fine-resolution Upper Weichselian and Holocene palynological record from Navarrés (Valencia, Spain) and a discussion about factors of Mediterranean forest succession. Review of Palaeobotany and Palynology 106, 209-236.

Combourieu Nebout, N., Turon, J. L., Zahn, R., Capotondi, L., Londeix, L., Pahnke, K. 2002. Enhanced aridity and atmospheric high-pressure stability over the western Mediterranean during the North Atlantic cold events of the past 50 k.y. Geology 30, 863-866.

García, D., Zamora, R., Gómez, J.; Hodar, J. 2002. Annual variability in reproduction of Juniperus communis L. in a Mediterranean mountain: relationship to seed predation and weather. Ecosciences, 9, (2), 251-255 pp.

García-Ruiz, J. M., Valero-Garcés, B., González-Sampériz, P., Lorente, A., Martí Bono, C., Beguería, S., Edwards, L. 2001. Stratified screes in the Central Spanish Pyrenees: Paleoclimatic implications. Permafrost and Periglacial Processes 12, 233-242 .

García-Ruiz, J. M., Valero-Garcés, B. L., Martí-Bono, C., González-Sampériz, P. 2003. Asynchroneity of maximum glacier advances in the central Spanish Pyrenees. Journal of Quaternary Science 18, 61-72.

González-Sampériz, P; Valero-Garcés, B; Carrión, J; Peña-Monné, JL; García-Ruiz, J.M., MartíBono, C. 2005. Glacial and Lateglacial vegetation in Northeastern Spain: new data and a review. Quaternary International, 140-141, 4-20. 
Griffiths, S. J., Street-Perrot, F. A., Holmes, J. A., Leng, M. J., and Tzedakis, C. (2002). Chemical and isotopic composition of modern water bodies in the Lake Kopais Basin, central Greece: analogues for the interpretation of the lacustrine sedimentary sequence. Sedimentary Geology 148, 79-103

Guiter, F., Triganon, A., Andrieu-Ponel, V., Ponel, P., Hébrard, J.-P., Nicoud, G., de Beaulieu, J.-L., Brewer, S., Guibal, F. 2005. First evidence of "in situ" Eemian sediments on the high plateau of Evian (Northern Alps, France): implications for the chronology of the Last Glaciation. Quaternary Science Reviews 24, 35-47.

Jalut, G; Serrat, D; Vilaplana, J., Andrieu, V. 1989. Last glaciation and deglaciation in the Pyrenees. Abstract, biennial Meeting of the European Union of Geosciences, EUG V, 20-23 March 1989. Strasbourg, 66-67.

Jalut, G., Montserrat, J., Fontugne, M., Delibrias, G., Vilaplana, J., Julià, R. 1992. Glacial to Interglacial vegetation changes in the northern and southern Pyrenees: Deglaciation, vegetation cover and chronology. Quaternary Science Reviews 11, 449-480.

Johnsen, S. J., Dahl-Jensen, D., Gundestrup, N. S., Steffensen, J. P., Clausen, H. B., Miller, H., Masson-Delmotte, V., Sveinbjörnsdóttir, A. E., White, J. 2001. Oxygen isotope and palaeotemperature records from six Greenland ice-core stations: Camp Century, Dye-3, GRIP, GISP2, Renland and NorthGRIP. Journal of Quaternary Sciences 16, 299-307.

Leng, M. and Marshall, J. D. 2004. Palaeoclimate interpretation of stable isotope data from lake sediment archives. Quaternary Science Reviews 23, 811-831.

Magri, D. 1999. Late Quaternary vegetation history at Lagacione near Lago di Bolsena (central Italy). Review of Palaeobotany and Palynology 106, 171-208.

Magri, D. and Parra, I. 2002. Late Quaternary western Mediterranean pollen records and African winds. Earth and Planetary Science Letters 200, 401-408.

McKenzie, J.A. 1985. Carbon isotopes and productivity in the lacustrine and marine environment. In: Stumm, W. (Ed.), Chemical Processes in Lakes, New York, Wiley, pp. 99-118.

Meyers, P. A. and Lallier-Vergès, E. (1999). Lacustrine Sedimentary Organic Matter Records of Late Quaternary Paleoclimates. Journal of Paleolimnology 21, 345. 
Meyers, P. A. (2003). Applications of organic geochemistry to paleolimnological reconstructions: a summary of examples from the Laurentian Great Lakes. Organic Geochemistry 34, 261-289.

Montjuvent G. and Nicoud, G. 1988. Modalités et chronologie de la déglaciation würmienne dans l'arc alpin occidental et les massifs français: synthèse et réflections. Bulletin de l’ Association Française pour l’ Etude du Quaternaire 2/3, 147-156.

Montserrat, J. 1992. Evolución glaciar y postglaciar del clima y la vegetación en la vertiente sur del Pirineo: estudio palinológico. Monografías del Instituto Pirenaico de Ecología-CSIC, Zaragoza, $147 \mathrm{pp}$

Moore, P; Webb, J.A., Collinson, A. 1991. An illustrated guide to pollen analysis. London. Hodder and Stroughton. 216 pp.

Moreno, A., Cacho, I., Canals, M., Prins, M. A., Sánchez-Goñi, M. F., Grimalt, J. O., Weltje, G. J. 2002. Saharan dust transport and high latitude glacial climatic variability: the Alboran Sea record. Quaternary Research 58, 318-328.

Pérez-Obiol, R. and Julià, R. 1994. Climate change on the Iberian Peninsula recorded in a 30.000 yr pollen record from Lake Banyoles. Quaternary Research 41, 91-98.

Pons, A. and Reille, M. 1988. The Holocene and upper Pleistocene pollen record from Padul (Granada, Spain): a new study. Palaeogeography, Palaeoclimatology, Palaeoecology 66, 243-263.

Prentice, I.C., Guiot, J., Harrison, S.P. 1992. Mediterranean vegetation, lake levels and palaeoclimate at the Last Glacial Maximum. Nature 360, 658-660.

Pujol, C. and Vergnaud-Grazzini, C. 1989. Paleoceanography of the Last Deglaciation in the Alboran Sea (Western Mediterranean). Stable isotopes and planktonic foraminiferal records. Marine Micropaleontology 15, 153-179.

Reille, M. and Lowe, J.L. 1993. A re-evaluation of the vegetation history of the eastern Pyrenees (France) from the end of the last glacial to the present. Quaternary Science Reviews 12, 47-77.

Reimer, P. J., Baillie, M. G. L., Bard, E., Bayliss, A., Beck, J. W., Bertrand, C. J. H., Blackwell, P. G., Buck, C. E., Burr, G. S., Cutler, K. B., Damon, P. E., Edwards, R. L., Fairbanks, R. G., Friedrich, M., Guilderson, T. P., Hogg, A. G., Hughen, K. A., Kromer, B., McCormac, G., Manning, S., Ramsey, C. B., Reimer, R. W., Remmele, S., Southon, J. R., Stuiver, M., Talamo, S., 
Taylor, F. W., van der Plicht, J., Weyhenmeyer, C. E. 2004. IntCal04. Terrestrial Radiocarbon Age Calibration, 0-26 Cal Kyr B.P. Radiocarbon 46, 1029-1058.

Roucoux, K.H; Abreu, L. de; Shackleton, N., Tzedakis, T. 2005. The response of NW Iberian vegetation to North Atlantic climate oscillations during the last 65 kyr. Quaternary Science Reviews 24, 1637-1653.

Ruddiman, W. and McIntyre, A., 1981. The North Atlantic Ocean during the last deglaciation. Palaeogeography, Palaeoclimatology, Palaeocology 35, 145-214.

Sánchez-Goñi, M. F., Cacho, I., Turon, J. L., Guiot, J., Sierro, F. J., Peypouquet, J.-P., Grimalt, J. O., Shackleton, N. J. 2002. Synchroneity between marine and terrestrial responses to millennial scale climatic variability during the last glacial period in the Mediterranean region. Climate Dynamics 19, 95-105.

Sancho, C., Peña-Monné, J.L., Lewis, C., McDonald, E., Rhodes, E. 2003. Preliminary dating of glacial and fluvial deposits in the Cinca river Valley (NE Spain): chronological evidences for the Glacial Maximum in the Pyrenees? In: Ruiz-Zapata, B., Dorado-Valiño, M., Valdeomillos, A., GilGarcía, M.J., Bardají, T., Bustamante, I., Mendizábal, I. (Eds.), Quaternary Climatic Changes and environmental crises in the Mediterranean Region. Alcalá de Henares, Madrid, pp. 169-174.

Sangiorgi, F., Capotondi, L., Brinkhuis, H. 2002. A centennial scale orgain-walled dinoflagellate cyst record of the last deglaciation in the South Adriatic Sea (Central Mediterranean). Palaeogeography, Palaeoclimatology, Palaeoecology 186, 199-216.

Seret G., Dricot, E., Wansard, G. 1990. Evidence for an early glacial maximum in the French Vosges during the last glacial cycle. Nature 346, 453-456.

Stockmarr, J. 1971. Tablets with spores used in absolute pollen analysis. Pollen et Spores 13, 614-621.

Talbot, M. R. 1990. A review of the palaeohydrological interpretation of carbon and oxygen isotopes in primary lacustrine carbonates. Chemical Geology 80, 261-279.

Turon, J. L., Lézine, A. M., Denèfle, M. 2003. Land-sea correlations for the last glaciation inferred from a pollen and dinocyst record from the Portuguese margin. Quaternary Research 59, 88-96.

Tzedakis, P.C; McManus, J; Hooghiemstra, H; Oppo, D., Wijmstra, T.A. 2003. Comparison of changes in vegetation in northeast Greece with records of climate variability on orbital and 
suborbital frequencies over the last 450000 years. Earth and Planetary Science Letters 212, 197212.

Valero-Garcés, B. L., Zeroual, E., Kelts, K. 1998. Arid phases in the western Mediterranean region during the last glacial cycle reconstructed from lacustrine records. In: Benito, G., Baker, V.R., Gregory, K.J. (Eds.), Paleohydrology and Environmental Change, pp. 67-80.

Valero-Garcés, B., González-Sampériz, P., Delgado-Huertas, A., Navas, A., Machín, J., Kelts, K. 2000. Lateglacial and Late Holocene environmental vegetational change in Salada Mediana, central Ebro Basin, Spain. Quaternary International 73 / 74, 29-46. 


\section{FIGURE CAPTIONS}

\section{Figure 1}

Location of the El Portalet peatbog in the Iberian Peninsula and map with the geology and the main geomorfological features. The El Portalet peatbog position is marked by a star.

\section{Figure 2}

Age control points used in the age model for the El Portalet sequence. The solid circles correspond to the AMS ${ }^{14} \mathrm{C}$ ages calibrated with the Calib 5.1 program (Reimer et al., 2004). The open circles are the oldest dates that were calibrated with the CALPAL program (http://www.calpal.de). A tie point marking the first expansion of Corylus is used to indicate the beginning of the Holocene (solid square). Numbers in bold mark the averaged sedimentation rates for three periods: 32,500-22,500; 17,500-13,000; 9000-5000 cal yr B.P. Both the YD and the LGM intervals are characterized by the lowest sedimentation rates in the sequence. Climatic events for the last 35,000 cal yr B.P. follow the INTIMATE terminology (Björck et al., 1998).

\section{Figure 3}

Lithological description and units of El Portalet sequence. Profiles of the mean grain size $(\mu \mathrm{m})$, percentage of organic matter and carbonate, stable isotopes $\left(\delta^{13} \mathrm{C}\right.$ and $\left.\delta^{18} \mathrm{O}\right)$ in carbonates and $\delta^{13} \mathrm{C}_{\text {org }}$ in bulk organic matter. The interpreted depositional environments, the correlation with pollen zones and the main climatic temporal divisions are also indicated. Hiati for LGM and YD intervals are indicated among Units 9-8 and Subunits 6B-6A.

\section{Figure 4}

Selected pollen taxa, total Pollen Concentration and calibrated dates from the El Portalet sequence. Three pollen groups have been included: Other Mesophytes (Alnus, Ulmus, Acer, Salix, Tilia, Fraxinus, Populus, Fagus, Juglans and Castanea); Other Steppe Taxa (Chenopodiaceae, Cichorioideae, Asteroideae, Carduae, Ephedra distachya type, Ephedra 
fragilis type, Plantago, Helianthemum, Rumex, Caryophyllaceae, Urticaceae, and Centaurea) and Hydro- and hygrophytes (Apiaceae, Ranunculaceae, Galium, Thalictrum, Typha, Sparganium, Cyperaceae, Isoetes, Myriophyllum, Potamogeton, Lemna, Nymphaea, Pedicularis, Utricularia and Lythrum). The correlation with sedimentary units and the main climatic temporal divisions are also indicated.

\section{Figure 5}

Selected data from the El Portalet sequence plotted against age and compared with the GRIP ice core (Johnsen et al., 2001) and the Alboran Sea SST record (Cacho et al., 2001) for the last 35,000 cal yr B.P. Palynological curves represent the percentages of Pinus, Juniperus, Betula and Corylus and Steppe taxa (Artemisia, Chenopodiaceae, Cichorioideae, Asteroideae, Carduae, Ephedra distachya type, Ephedra fragilis type, Plantago, Helianthemum, Rumex, Caryophyllaceae, Urticaceae, and Centaurea). Variations of $\delta^{13} \mathrm{C}_{\mathrm{org}}$ in bulk organic matter are also plotted. Gray bands mark the Heinrich events and gray dashed bands indicate the situation of the Younger Dryas Stade and the Lateglacial Maximum. Dashed lines point to other cold events in Greenland core.

\section{Figure 6}

Selected data from the El Portalet sequence plotted versus age and compared with the GRIP ice core (Johnsen et al., 2001) and the Alboran Sea SST record (Cacho et al., 2001) for the last 18,000 cal yr B.P. Palynological curves represent the percentages of Pinus, Juniperus, Betula, Corylus and Steppe taxa (Artemisia, Chenopodiaceae, Cichorioideae, Asteroideae, Carduae, Ephedra distachya type, Ephedra fragilis type, Plantago, Helianthemum, Rumex, Caryophyllaceae, Urticaceae, and Centaurea). Variations of $\delta^{13} \mathrm{C}_{\mathrm{org}}$ in bulk organic matter together with the percentage of carbonate are also plotted. Gray bands mark the cold periods during the Lateglacial (1 to 5). The sequence of climatic events for the last 18,000 cal yr B.P. is shown following the INTIMATE terminology (Björck et al., 1998). 
FIGURE 1

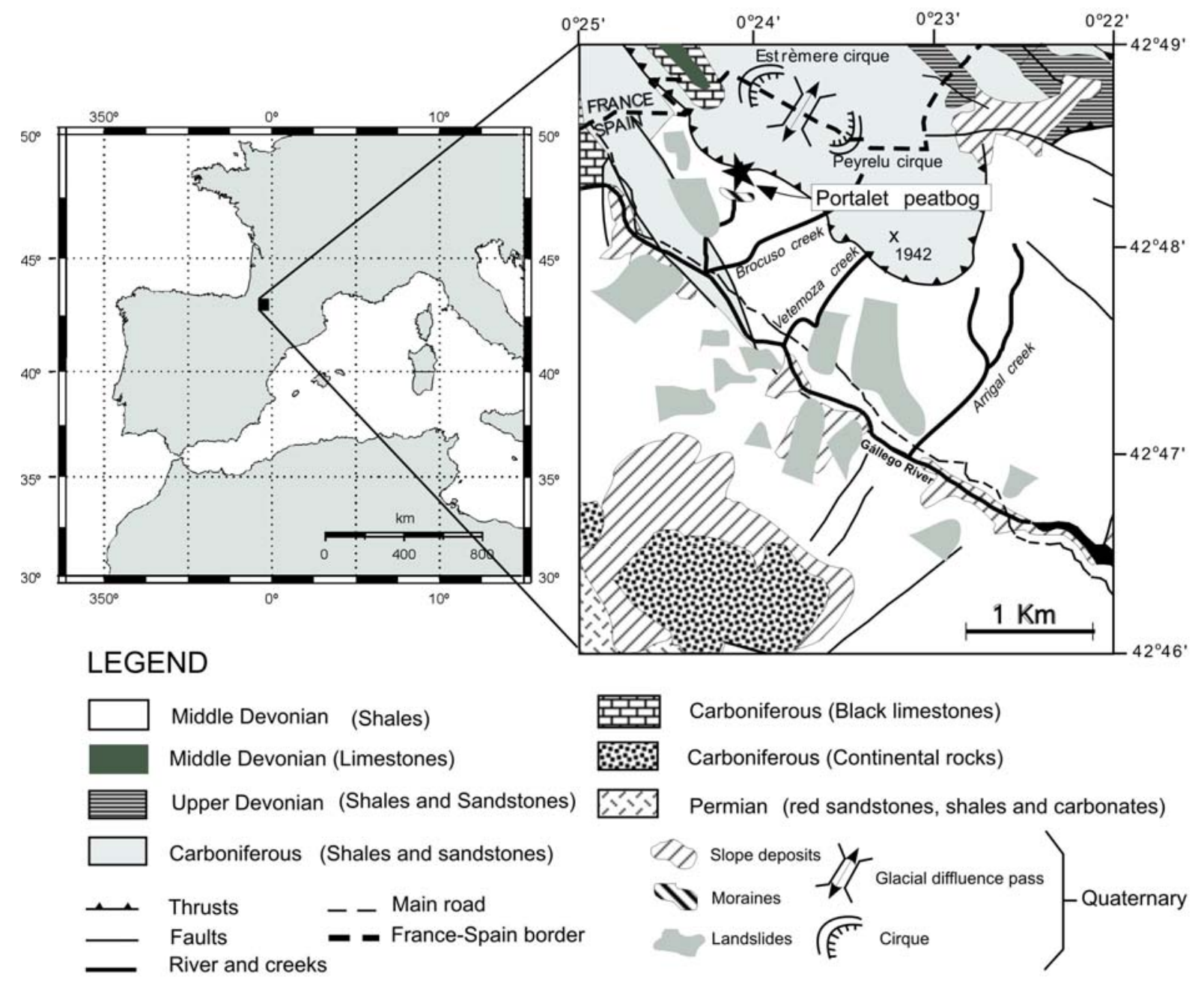


FIGURE 2

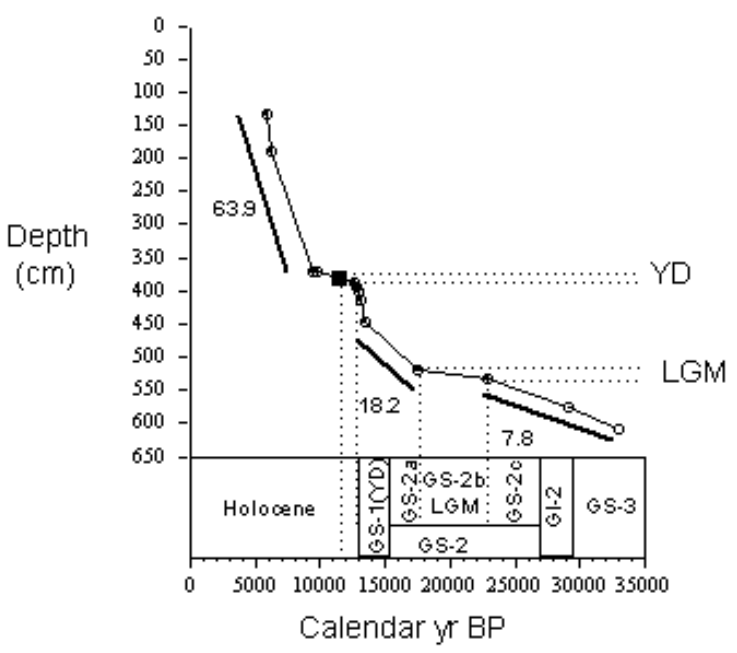


FIGURE 3

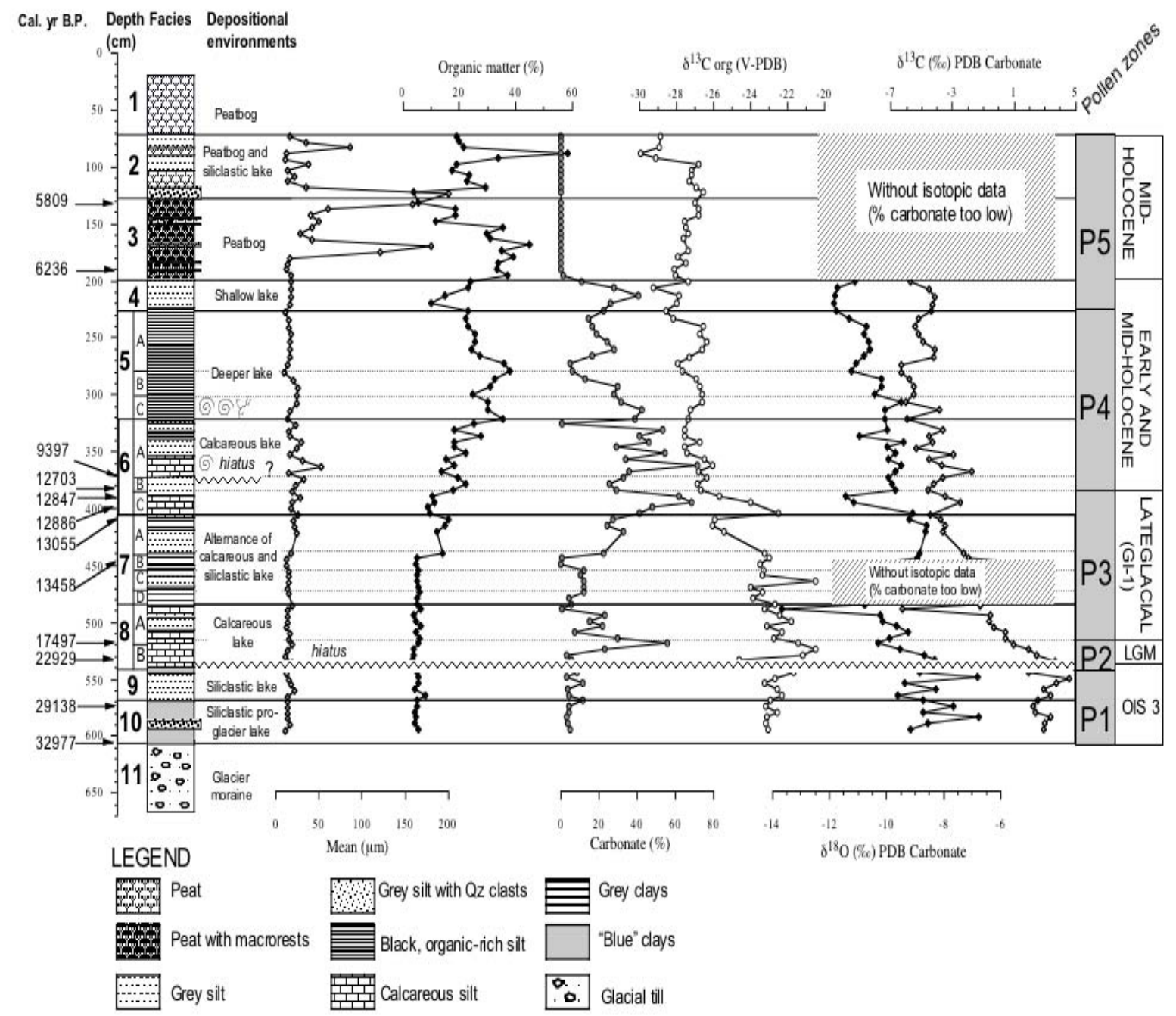


FIGURE 4

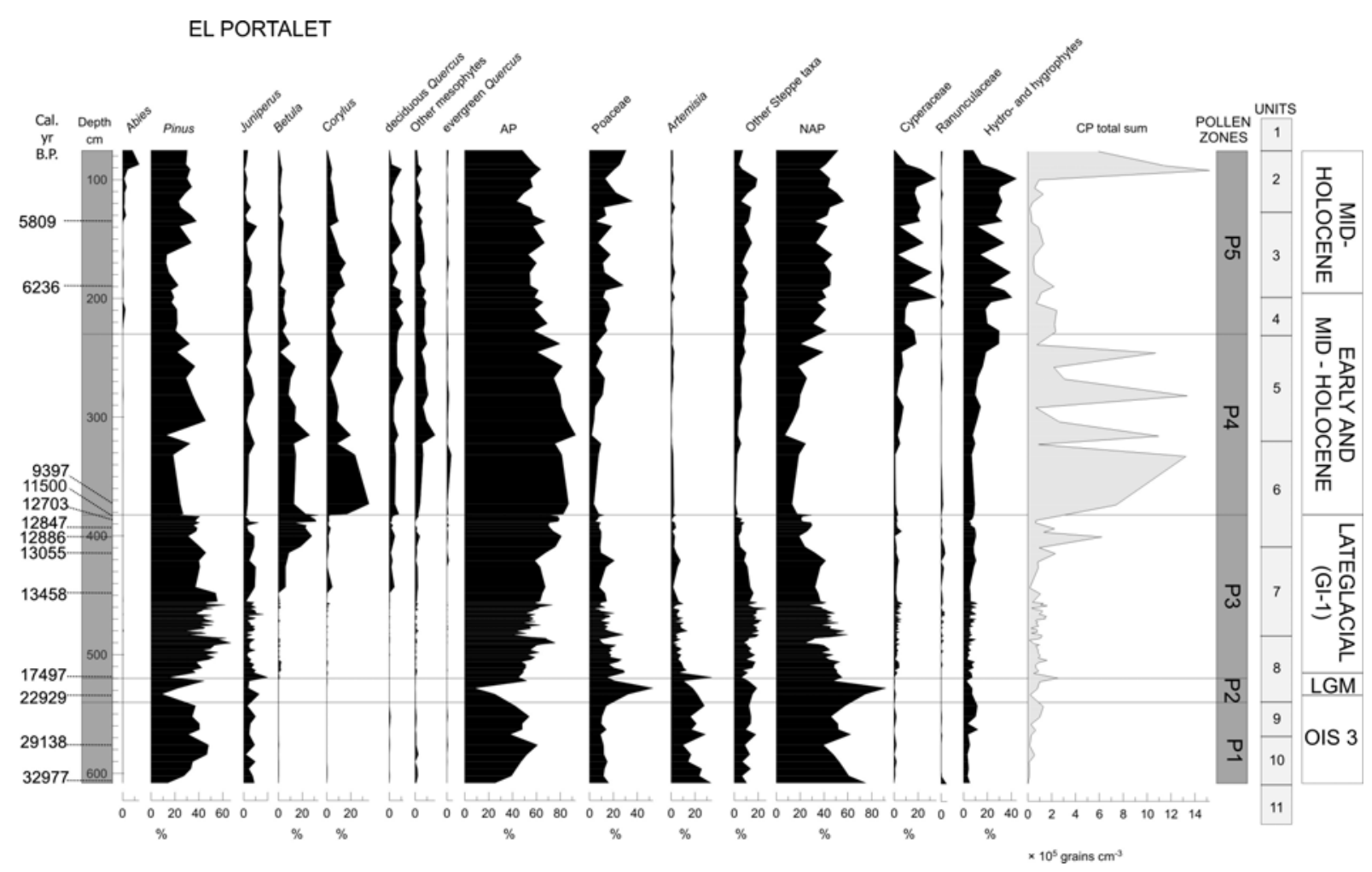


FIGURE 5

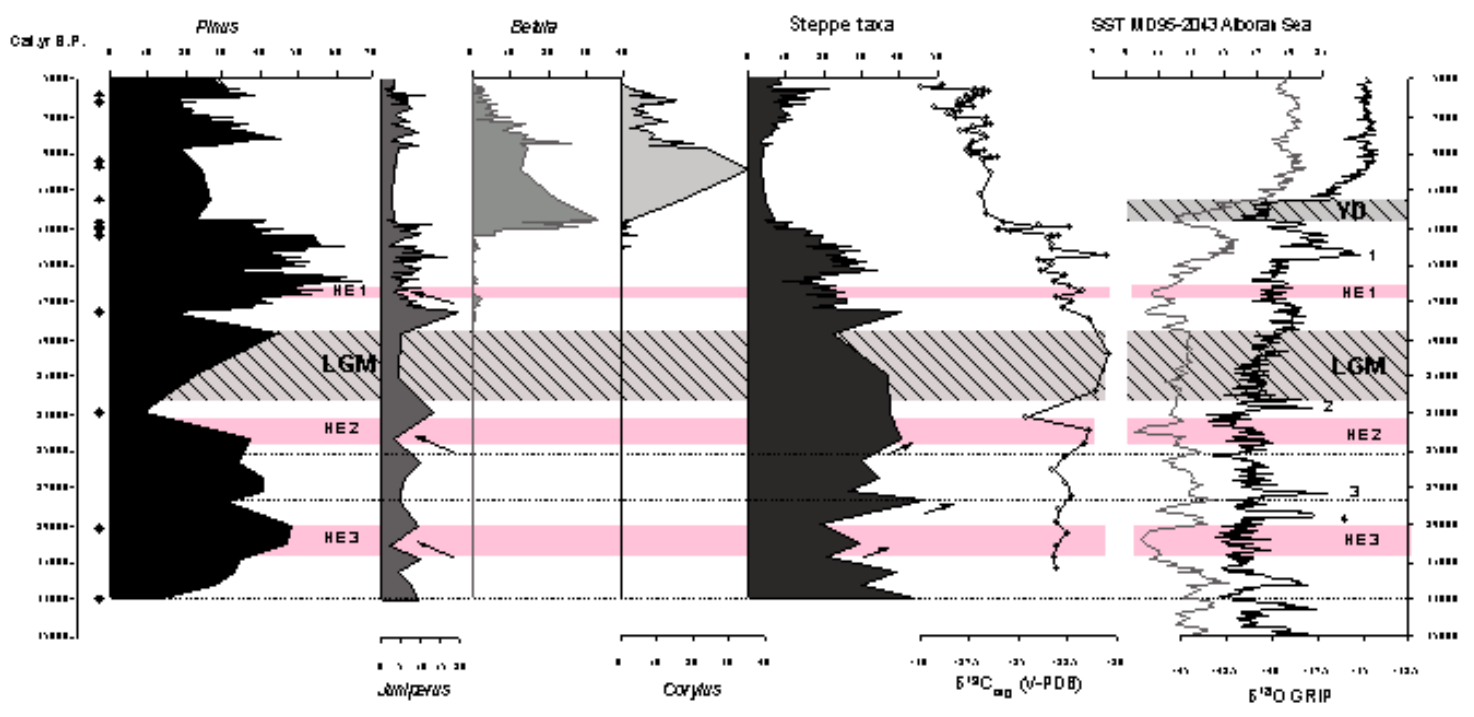


FIGURE 6

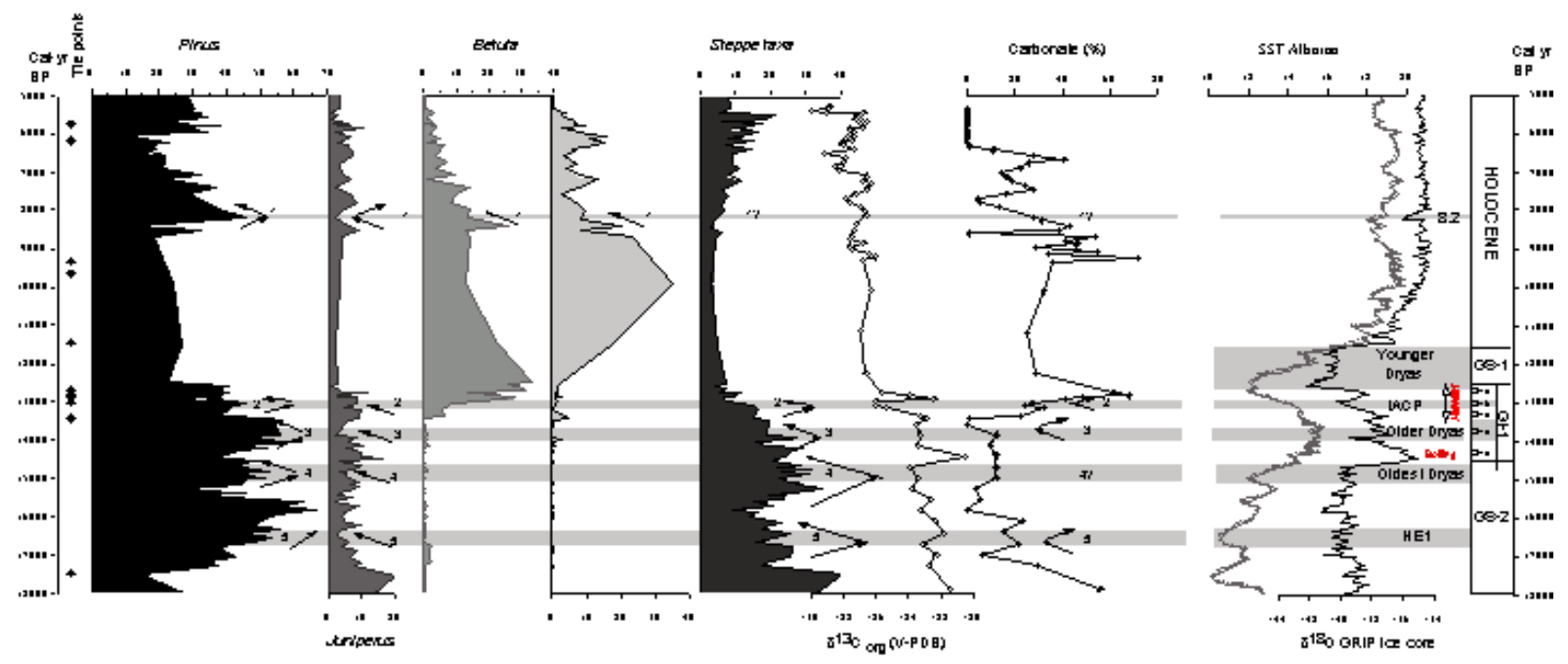


Table 1. Radiocarbon age determinations on sediment samples from the El Portalet peatbog sequence. See text for a more detailed explanation.

\begin{tabular}{cccccc}
$\begin{array}{c}\text { Depth } \\
(\mathrm{cm})\end{array}$ & $\begin{array}{c}\text { Laboratory } \\
\text { code }\end{array}$ & $\begin{array}{c}{ }^{14} \text { C AMS age } \\
\text { (yr B.P.) }\end{array}$ & $\begin{array}{c}\text { Calibrated age } \\
\text { (cal yr B.P) }(\text { range } 2 \sigma)\end{array}$ & Type of sample & Calibration \\
\hline 135.4 & AA54266 & $5058 \pm 55$ & $5706-5913$ & Pollen concentrate & INTCAL04 \\
189.3 & NSRL11967 & $5410 \pm 55$ & $6171-6302$ & $\begin{array}{c}\text { Pollen concentrate } \\
\text { Wood fragment }\end{array}$ & INTCAL04 \\
371.8 & NSRL11967 & $8420 \pm 80$ & $9251-9544$ & INTCAL04 \\
371.8 & NSRL11968 & $8610 \pm 90$ & $9465-9889$ & Pollen concentrate & INTCAL04 \\
386.7 & Beta 202347 & $10,630 \pm 50$ & $12,591-12,816$ & Pollen concentrate & INTCAL04 \\
393 & Beta196245 & $10,840 \pm 40$ & $12,807-12,887$ & Pollen concentrate & INTCAL04 \\
400.4 & AA54263 & $10,884 \pm 84$ & $12,773-13,000$ & Pollen concentrate & INTCAL04 \\
414.2 & AA54264 & $11,148 \pm 80$ & $12,911-13,199$ & Pollen concentrate & INTCAL04 \\
448.0 & AA54260 & $11,587 \pm 85$ & $13,268-13,648$ & Pollen concentrate & INTCAL04 \\
519.0 & AA54261 & $14,546 \pm 98$ & $17,028-17,966$ & Pollen concentrate & INTCAL04 \\
533.0 & AA58485 & $19,250 \pm 120$ & $22,485-23,374$ & Pollen concentrate & INTCAL04 \\
577.0 & AA54259 & $24,170 \pm 240$ & $28,717-29,559$ & Pollen concentrate & CALPAL2004 \\
608.0 & NSRL11969 & $28,300 \pm 370$ & $32,183-33,773$ & Pollen concentrate & CALPAL2004
\end{tabular}


Table 2. Correlation of the main events during the last 32,000 yrs between GRIP ice core and the El Portalet sequence. Both pollen and sedimentological signals from El Portalet are indicated including depth $(\mathrm{cm})$ and age (cal. yr B.P.*10 ${ }^{3}$ ) for every period. (a) GRIP date from Alley et al. (1997); (b) dates from INTIMATE group (Björck et al., 1998) and (c) dates from visual observation of the $\delta^{18} \mathrm{O}$ GRIP record

(Figs. 5 and 6).

\begin{tabular}{|c|c|c|c|c|c|c|c|}
\hline \multirow{2}{*}{ Events } & \multirow{2}{*}{$\begin{array}{c}\text { GRIP } \\
\text { Age (Cal. yr } \\
\left.\text { B.P. } * \mathbf{1 0}^{3}\right)\end{array}$} & \multicolumn{3}{|c|}{ EL PORTALET Pollen signal } & \multicolumn{3}{|c|}{ EL PORTALET Sedimentological signal } \\
\hline & & $\begin{array}{l}\text { Depth } \\
\text { (cm) }\end{array}$ & $\begin{array}{l}\text { Age (Cal. yr } \\
\left.\text { B.P. } * 10^{3}\right)\end{array}$ & Data & $\begin{array}{l}\text { Depth } \\
\text { (cm) }\end{array}$ & $\begin{array}{l}\text { Age (Cal. yr } \\
\text { B.P. } * 10^{3} \text { ) }\end{array}$ & 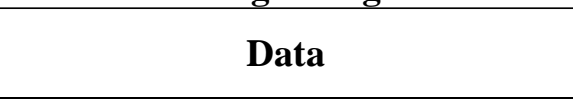 \\
\hline Event 8.2 & 8.4-8 (a) & $312-290$ & $8.3-8$ & $\begin{array}{l}\text { Decrease in Juniperus, Betula, Corylus, } \\
\text { deciduous Quercus and other mesophytes. } \\
\text { Increase in NAP and hydro- and } \\
\text { hygrophytes (mainly Cyperaceae) }\end{array}$ & $320-292$ & $8.5-8$ & $\begin{array}{l}\text { Subunit 5C: High } \delta^{13} \mathrm{C}_{\text {org }} \text { values and } \\
\text { shallower deposition facies (abundant } \\
\text { mollusk and macrophyte remains) }\end{array}$ \\
\hline YD (GS-1) & $12.65-11.5(\mathrm{~b})$ & $\sim 385$ & $12.6-11.5$ & No signal, hiatus & $\sim 385$ & $12.6-11.5$ & No signal, hiatus \\
\hline \multirow{3}{*}{ 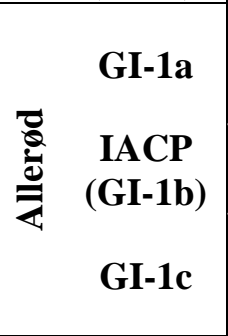 } & 12.9-12.65 (b) & $415-385$ & $13-12.6$ & $\begin{array}{l}\text { Betula development, increase in Corylus, } \\
\text { Quercus and other mesophytes. Increase } \\
\text { in Ranunculaceae. Decrease in steppe taxa }\end{array}$ & $408-385$ & $12.9-12.6$ & $\begin{array}{l}\text { Subunit 6C: Massive, dark organic silts, } \\
\text { with low macro-rest content }\end{array}$ \\
\hline & $13.15-12.9$ (b) & $425-415$ & $13.1-13$ & $\begin{array}{c}\text { Steppe taxa increase, Juniperus decreases. } \\
\text { Ranunculaceae decrease }\end{array}$ & $419-408$ & 13.1-12.9 & $\begin{array}{l}\text { Upper part Subunit 7A: Gray } \\
\text { siliciclastic silts, low carbonate content }\end{array}$ \\
\hline & 13.9-13.15 (b) & $447-425$ & $13.4-13.1$ & $\begin{array}{l}\text { First Betula development. Increase in } \\
\text { Juniperus., Corylus, Quercus and other } \\
\text { mesophytes. Ranunculaceae increase }\end{array}$ & $440-419$ & $13.4-13.1$ & $\begin{array}{l}\text { Lower part Subunit 7A: Massive, dark } \\
\text { organic silts, with low macro-rest } \\
\text { content }\end{array}$ \\
\hline $\begin{array}{c}\text { Older Dryas } \\
\text { (GI-1d) }\end{array}$ & $14.05-13.9$ (b) & $458-447$ & $14-13.4$ & Steppe taxa increase, Juniperus decreases & $458-440$ & $14-13.4$ & $\begin{array}{c}\text { Subunit 7B: Gray siliciclastic silts, low } \\
\text { carbonate content }\end{array}$ \\
\hline $\begin{array}{l}\text { Bölling } \\
\text { (GI-1e) }\end{array}$ & $14.7-14.05$ (b) & $470-458$ & $14.7-14$ & $\begin{array}{l}\text { Juniperus increase. Low increase in } \\
\text { mesophytes }\end{array}$ & $470-458$ & $14.7-14$ & $\begin{array}{l}\text { Subunit 7C: Greenish-gray, carbonate- } \\
\text { rich silt layers }\end{array}$ \\
\hline $\begin{array}{l}\text { Oldest } \\
\text { Dryas }\end{array}$ & $15.1-14.7$ (c) & $478-470$ & $15.2-14.7$ & Steppe taxa increase, Juniperus decreases & $485-470$ & $15.5-14.7$ & $\begin{array}{c}\text { Subunit 7D: Gray siliciclastic silts, low } \\
\text { carbonate }\end{array}$ \\
\hline HE1 & $16.8-16.2(\mathrm{c})$ & $502-498$ & $16.5-16.3$ & Steppe taxa increase, Juniperus decreases & $502-498$ & $16.5-16.3$ & $\begin{array}{l}\text { Mid part Subunit 8A: Gray siliciclastic } \\
\text { silts, low carbonate }\end{array}$ \\
\hline LGM & $22.5-18.5(\mathrm{c})$ & $\sim 530$ & $22.5-18$ & Abrupt peaks of Poaceae and Pinus & $\sim 530$ & $22.5-18$ & Erosive surface, hiatus \\
\hline HE2 & $24.5-23.2$ (c) & $550-537$ & $25.1-23.5$ & Steppe taxa increase, Juniperus decreases & $545-537$ & $24.6-23.5$ & Top of Unit 9: Bluish gray silts \\
\hline HE3 & $31-29$ (c) & $590-580$ & 30.7-29.5 & Steppe taxa increase, Juniperus decreases & $595-585$ & $31.4-30.1$ & $\begin{array}{l}\text { Silty-sandier layer intercalated in the } \\
\text { pro-glaciar sediments (Unit 10) }\end{array}$ \\
\hline
\end{tabular}

